\title{
The land issue: Power struggles between the central government and local authorities
}

\section{Marie-Hélène Schwoob}

Translator. N. Jayaram

\section{OpenEdition \\ Journals}

\section{Electronic version}

URL: http://journals.openedition.org/chinaperspectives/5821

DOI: 10.4000/chinaperspectives.5821

ISSN: 1996-4617

\section{Publisher}

Centre d'étude français sur la Chine contemporaine

\section{Printed version}

Date of publication: 30 March 2012

Number of pages: 66-67

ISSN: 2070-3449

\section{Electronic reference}

Marie-Hélène Schwoob, «The land issue: Power struggles between the central government and local authorities », China Perspectives [Online], 2012/1 | 2012, Online since 30 March 2012, connection on 15 September 2020. URL : http://journals.openedition.org/chinaperspectives/5821

(c) All rights reserved 
This section, prepared by the Asia Centre (www.centreasia.org), draws mainly on the press in Chinese, aiming to reflect the point of view of the People's Republic of China on international questions and issues related to Greater China.

\section{China Analvsìs Les Nouvelles de Chine}

\section{The land issue: Power struggles between the central government and local authorities}

Analysis by Marie-Hélène Schwoob based on:

- Zhang Qianfang, (1) "Uncertain conservation of cultivable land in China," Changcheng Yuebao, 11 June 2011.

- Mao Yushi, (2) "Key to problem of cultivable land in China lies in rational and equitable use," Shidai zhoubao, 3 November 2011.

$\mathrm{O}$ ver the past few years, development policy initiatives aimed at the Chinese countryside have intensified. The measures stemming from the five-year plan to reduce rural poverty, published last November, show how much of a priority the issue has assumed for the government. (3) But at the core of the "rural question" lies the thorny issue of land, a limited resource much in demand amid rapid urbanisation that requires new real estate, and for maintaining agriculture production levels. It has stoked increasing worries for the central government leadership as well as for Chinese people at large.

The current system for protecting cultivable land aimed at ensuring agricultural production levels and food security prohibits free conversion and sale in the open market. However, Zhang Qianfang points out, the gap between the value of cultivated land and of urban land puts considerable pressure on the former. The low price of agricultural products - and thus of income from cultivated land - the lack of rural infrastructure, and a series of other factors greatly undermine the value of farmland. Urbanisation leads to a significant appreciation in land value, and so rural land earmarked for agriculture gets taken over thanks to the need for change.

This is reflected in the change of administrative status of many rural areas. In 2001, the national coverage rate of urban cities had risen to 42.6 percent of the country - against just 20 percent in 1990. Through this process, land sales have helped local governments amass huge profits.

However, as Zhang has stressed, the ever-increasing needs of accelerated urbanisation and the particularly lucrative nature of farmland sales have also sparked a large number of violent land disputes, which have emerged as a major phenomenon. Meanwhile, accelerated development is causing significant loss of arable land.

In order to combat these trends, the government has sought to implement in recent years a series of measures aimed at protecting arable land from the ravages of urbanisation. In June 2006, the Ministry of Land and Resources decided to vest with the central government the power to approve any modification to the eventual use of land. However, this new restriction failed to stem the loss of agricultural land. Zhang's article points to cases of illegal land use that have proliferated in recent years. A People's Daily article, meanwhile, reports the conclusions of an evaluation report on five years' implementation of the land supervision system, reporting a large number of violations of the law on land conservation: over five years, almost 8,500 people were sanctioned by the Party's Discipline Inspection Commission, and more than 1,500 faced judicial proceedings. But a total of more than 64,000 instances of violations of land control laws have been reported. (4)

Most authors agree on the inefficiency of the national land control policies, noting the glaring contradictions between national and local interests. Meanwhile, Zhang acknowledges that given the contradictions between local interests and those of farmers, the central government seems to have no policy option other than the 1.8 billion mu (120 million hectares) "red line" as the absolute minimum national cultivable land area. Zhang notes the need to protect arable land against the pressure of massive urbanisation in order to ensure food security in the face of growing demand.

But the authors deem unrealistic the adoption of a national system to ensure adherence to the "red line." The current system for limiting land conversion is highly inefficient. The national land management system suffers from insufficient or inexact information. Moreover, it is apparently impossible to establish appropriate mechanisms to rein in local governments' penchant for allowing illegal conversion of arable land for much more lucrative building projects. The system does not take into consideration local interests and the needs of economic development, especially in coastal areas. Zhang adds that the unrealistic aspects of land management undermine to the authority of the whole system. Rational land planning has to be adopted, but it is an uphill task, as any rational process must be based on complete information. Further, national authorities are not in a position to survey and control real use of farmland and to resolve conflicts of interest. Adoption of new techniques of information gathering and augmentation of control staff and arrangements at all levels seems essential for realising an effective system of land management.

Mao Yushi denounces the return to economic planning implied in such a system of land management. He holds that the state must not usurp the market's role to take decisions that go against specific local interests. Mao considers it impossible to precisely calculate the nationwide need for arable land. In his view, prioritising one function over another for a piece of land depends entirely on local conditions, and it makes no sense to systematically accord primacy to farming. He believes in optimal allocation of re-

\footnotetext{
Zhang Qianfang teaches at Peking University's Public Law Research Centre. Mao Yushi is an economist and chairman of the think tank Unirule Institute of Economics. Programme text online, www.gov.cn/jrzg/2011-12/01/content_2008462.htm (consulted on 7 February 2012).

4. "Local governments face institutional obstacles in managing their land," Renmin ribao - People's
} Daily, 25 November 2011. 
sources through market forces: if demand for food is too great in relation to national production, farm product prices will rise and contribute to raising the value of agricultural land, thus leading farmers to resume cultivating land they had previously abandoned.

To tackle the supply-demand imbalance, Mao recommends developing national and international trade in food products. That, he says, would not only help secure food supplies, but would also bring down the total cost of food production. Mao cites the example of Japan and South Korea as food importing countries.

However, the population levels of these importing countries are hardly comparable to that of China. Also, a shortfall in national agriculture production would have an impact on international markets, raising the risks of unstable world prices for agricultural products.
The accentuation of governmental efforts at moderating rising prices of food products seems to indicate that regulation through market forces is not the best option.

Zhang concludes that China's urbanisation is in any case an inexorable trend, that social problems stemming from land conversion are thus unavoidable, and that the process should either be strengthened or suspended. While hoping that urbanisation would lead to positive fallout in rural areas too, the central government apparently has no choice but to face up to divergent interests - its own, those of local governments, those of farmers, and those of the rest of the population.

I Translated by N. Jayaram 